\title{
Studi Stabilitas Lereng Clay Shale di Kalimantan dengan Menggunakan Metode Kesetimbangan Batas dan Pendekatan Probabilistik dan Deterministik
}

\author{
Ignatius Tommy PRATAMA ${ }^{1}$ \\ ${ }^{1}$ Jurusan Teknik Sipil, Fakultas Teknik, Universitas Katolik Parahyangan, \\ email: tommyignatius@unpar.ac.id
}

\author{
Sejarah artikel \\ Makalah ini dipresentasikan di Seminar Nasional Riset \\ dan Teknologi Terapan (Ritektra) X pada tanggal 12 Agustus 2021 \\ Dalam bentuk revisi: \\ Tersedia online:
}

23 Agustus 2021

30 September 2021

\begin{abstract}
Deterministic and probabilistic slope stability analyses on a clay shale slope in Kalimantan were carried out in this study by using the limit equilibrium method to estimate the safety factor and the probability of failure of the slope before and after the installation of slope reinforcement. The steel pipe piles rows and woodpiles (so-called cerucuk) were used as the slope reinforcement in this study. The back analysis results show that a translational landslide occurred in clay shale soil with the effective cohesion of 1,5 $\mathrm{kN} / \mathrm{m}^{2}$ and an average residual friction angle of about 8,5 to $10,3^{\circ}$. Moreover, the use of the slope reinforcement and excavation to a depth of $3 \mathrm{~m}$ from the existing ground surface could increase the factor of safety to 1,25. The results of the probabilistic analysis using the Monte-Carlo simulation with a number of simulations varied from 2.000 to 20.000 show that the use of slope reinforcement on a clay shale slope could decrease the probability of failure to 0,05\%-0,28\%. In addition, the sensitivity analysis results indicate that the groundwater elevation had the most significant influence on the stability of a clay shale slope.
\end{abstract}

Keywords: slope stability analysis, probabilistic analysis, clay shale, limit equilibrium method

\begin{abstract}
Abstrak
Analisis deterministik dan probabilistik kestabilan lereng tanah clay shale di Kalimantan dilakukan di dalam studi ini dengan menggunakan metode kesetimbangan batas untuk mengestimasikan nilai faktor keamanan dan probabilitas kegagalan lereng sebelum dan sesudah pemasangan perkuatan lereng. Hasil analisis balik mengindikasikan bahwa longsoran translasi terjadi pada tanah clay shale dengan nilai kohesi efektif sebesar $1,5 \mathrm{kN} / \mathrm{m}^{2}$ dan nilai rata-rata sudut geser residu efektif berkisar antara $8,5^{\circ}$ hingga 10,3 $3^{\circ}$. Kemudian, penggunaan perkuatan lereng berupa barisan tiang pancang pipa baja dan cerucuk kayu dan penggalian sedalam $3 \mathrm{~m}$ dari permukaan tanah eksisting dapat meningkatkan faktor keamanan lereng menjadi 1,25. Hasil analisis probabilistik berbasis simulasi Monte-Carlo dengan jumlah simulasi yang bervariasi antara 2.000 hingga 20.000 simulasi menunjukkan bahwa penggunaan struktur perkuatan lereng dapat menurunkan nilai probabilitas kegagalan hingga ke nilai 0,05\%-0,28\%. Berdasarkan hasil analisis sensitivitas, elevasi muka air tanah memiliki pengaruh paling signifikan di dalam perhitungan faktor keamanan lereng clay shale.
\end{abstract}

Kata kunci: analisis kestabilan lereng, analisis probabilitas, clay shale, metode kesetimbangan batas

\section{Pendahuluan}

Ketidakpastian di dalam analisis kestabilan lereng dapat bersumber dari ketidakpastian model (model uncertainty) dan parameter tanah, khususnya ketidakpastian parameter kekuatan tanah. Hal ini menyebabkan suatu nilai faktor keamanan (FK) yang sama dapat menggambarkan tingkat risiko kegagalan yang berbeda-beda (Duncan, 2000; Juang et al., 2015; Zhou et al., 
2020). Metode probabilistik merupakan salah satu pendekatan yang umum digunakan untuk memperhitungkan ketidakpastian di dalam analisis kestabilan lereng, khususnya pada analisis kestabilan lereng dengan metode kesetimbangan batas (limit equilibrium method, LEM). Di dalam metode probabilistik, input parameter tanah diasumsikan sebagai variabel acak dengan distribusi probabilitas yang ditentukan berdasarkan statistik, dan kemudian menghasilkan nilai probabilitas kegagalan $\left(\mathrm{P}_{\mathrm{f}}\right)$ untuk menggambarkan kestabilan lereng selain dari nilai faktor keamanannya (Zhou et al., 2020). Salah satu metode probabilistik yang umum digunakan, khususnya di dalam analisis kestabilan lereng dan relatif sederhana adalah simulasi MonteCarlo (Tobutt, 1982; Wang et al., 2010). Simulasi Monte-Carlo merupakan simulasi penyelesaian masalah secara berulang dengan nilai variabel-variabel yang dipilih secara acak untuk setiap pengulangannya (Lacasse \& Nadim, 1998). Walaupun analisis probabilistik berbasis simulasi Monte-Carlo relatif sederhana dan memiliki beberapa keunggulan, jumlah studi analisis kestabilan lereng dengan pendekatan probabilistik, khususnya yang dilakukan pada tanah-tanah problematik seperti clay shale masih relatif terbatas (El-Ramly et al., 2003). Hal ini disebabkan insinyur geoteknik pada umumnya kurang familier dengan konsep analisis probabilitas (Duncan, 2000; Duncan et al., 2014).

Clay shale merupakan salah satu tanah problematik yang menyebabkan banyak terjadi kegagalan lereng di Indonesia (Jitno et al., 2019, Irsyam et al., 2007, Pratama \& Arif, 2021). Hal ini disebabkan oleh karakteristik material clay shale yang mudah lapuk ketika terekspos dengan udara atau air (Gouw et al., 2019). Gartung (1986) melaporkan bahwa tanah clay shale pada kondisi lapuk memiliki nilai sudut geser residu yang sangat rendah, yaitu $9^{\circ}$ dan tidak memiliki nilai kohesi. Sehingga, studi ini bertujuan untuk mengevaluasi kestabilan lereng tanah clay shale di Kalimantan dengan menggunakan pendekatan probabilitas untuk mendapatkan nilai $P_{f}$ pada kondisi lereng eksisting dan lereng dengan struktur perkuatan barisan tiang pancang pipa baja dan cerucuk kayu. Analisis kestabilan lereng dilakukan dengan menggunakan metode kesetimbangan batas untuk memperoleh nilai faktor keamanan (FK) berdasarkan metode Spencer (1973). Selain itu, analisis sensitivitas juga dilakukan di dalam studi ini untuk mengobservasi pengaruh perubahan nilai berat isi tanah, sudut geser dalam efektif tanah $\left(\phi^{\prime}\right)$, dan tekanan air pori yang dapat diakibatkan oleh fluktuasi muka air tanah terhadap nilai FK.

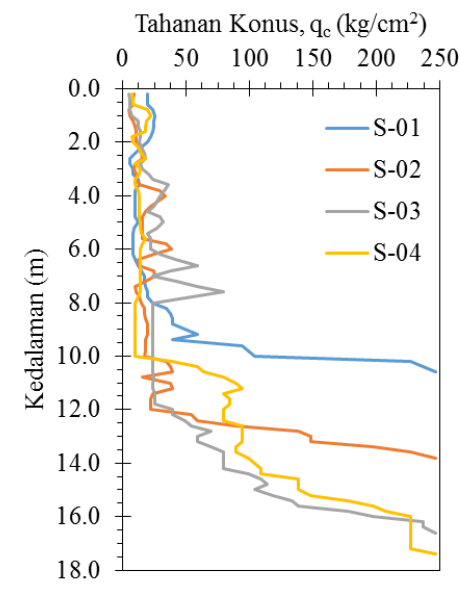

(a)

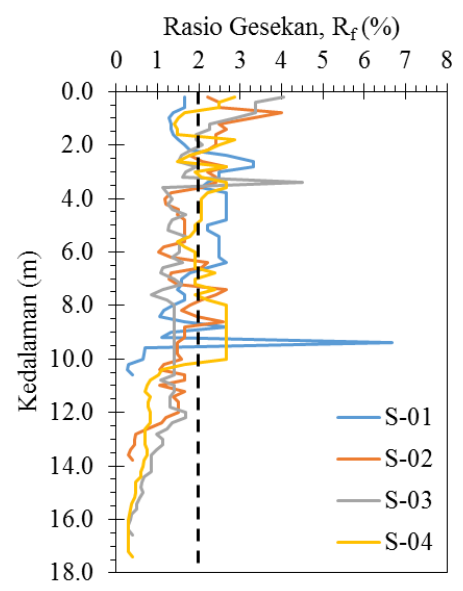

(b)

Gambar 1. Kurva (a) tahanan ujung $\left(\mathrm{q}_{\mathrm{c}}\right)$ dan (b) rasio gesekan $\left(\mathrm{R}_{\mathrm{f}}\right)$ terhadap kedalaman hasil uji sondir

\section{Kondisi Lereng Eksisting}

Lereng tinjauan di dalam studi kasus ini berlokasi di Provinsi Kalimantan Timur. Pratama \& Arif (2021) menjelaskan bahwa tanah longsor terjadi di lokasi ini akibat penimbunan berlebih dengan ketinggian maksimum mencapai $8 \mathrm{~m}$ yang dilakukan dalam waktu yang relatif singkat di atas lapisan tanah clay shale. Selain itu, kegagalan lereng timbunan juga diakibatkan oleh jenis material timbunan, proses penimbunan, dan pemadatan tanah yang kurang baik. Kegagalan lereng terjadi pada lereng dengan kemiringan yang relatif landai, yaitu 1V:10,5H (1 
vertikal:10,5 horizontal). Pratama \& Arif (2021) juga menjelaskan bahwa jenis longsoran yang terjadi di lokasi ini merupakan jenis longsoran translasi dengan panjang zona pengaruh mencapai kurang lebih $100 \mathrm{~m}$ berdasarkan hasil observasi lapangan.

Uji sondir kemudian dilakukan di 4 titik berbeda di dalam zona longsoran untuk mengetahui kondisi tanah pasca tanah longsor. Gambar 1 menggambarkan nilai tahanan ujung $\left(\mathrm{q}_{\mathrm{c}}\right)$ dan rasio gesekan $\left(\mathrm{R}_{\mathrm{f}}\right)$ terhadap kedalaman untuk setiap titik sondir. Gambar 1 juga menunjukkan bahwa lokasi tanah keras berada di kedalaman 9,4 m hingga 13,8 $\mathrm{m}$ di bawah permukaan tanah dengan rentang nilai $\mathrm{q}_{\mathrm{c}}$ berkisar antara $89-247,2 \mathrm{~kg} / \mathrm{cm}^{2}$ dan nilai $\mathrm{R}_{\mathrm{f}}$ berkisar antara $0,3-0,7 \%$. Sementara itu, lapisan tanah yang berada di atas lapisan tanah keras memiliki rentang nilai $\mathrm{q}_{\mathrm{c}}$ dan $R_{\mathrm{f}}$ secara berturut-turut berkisar antara 4,9-98,9 kg/cm ${ }^{2}$ dan $0,7-6,7 \%$. Pratama \& Arif (2021) berdasarkan hasil uji sondir dan hasil analisis numerik mengindikasikan bahwa lokasi bidang gelincir berada di permukaan lapisan tanah keras. Sebagai tambahan, hasil observasi sumur pantau menunjukkan bahwa muka air tanah berada pada kedalaman 1,4 $\mathrm{m}$ hingga 4,8 $\mathrm{m}$ di bawah permukaan tanah.

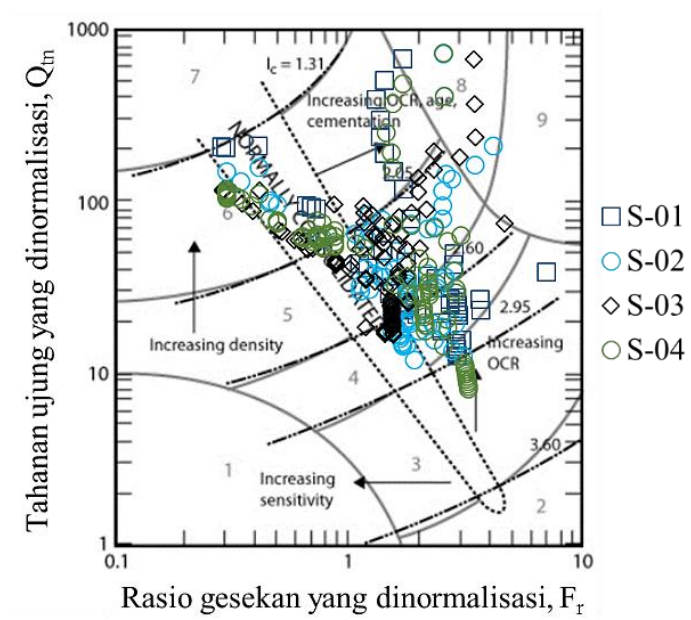

\begin{tabular}{|c|c|}
\hline Zona & Tipe Perilaku Tanah (SBT) \\
\hline 1 & Tanah butir halus sensitif \\
\hline 2 & Lempung - tanah organik \\
\hline 3 & $\begin{array}{l}\text { Tanah lempung: lempung hingga lempung } \\
\text { lanauan }\end{array}$ \\
\hline 4 & $\begin{array}{l}\text { Campuran lanau: lanau lempungan dan } \\
\text { lempung lanauan }\end{array}$ \\
\hline 5 & $\begin{array}{l}\text { Campuran pasir: pasir lanauan hingga lanau } \\
\text { pasiran }\end{array}$ \\
\hline 6 & $\begin{array}{l}\text { Tanah pasir: pasir bersih hingga pasir } \\
\text { lanauan }\end{array}$ \\
\hline 7 & Pasir padat hingga pasir kerikilan \\
\hline 8 & Pasir kaku hingga pasir lempungan \\
\hline 9 & $\begin{array}{l}\text { Tanah butir halus kaku (terkonsolidasi } \\
\text { berlebih atau tersementasi) }\end{array}$ \\
\hline
\end{tabular}

Gambar 2. Klasifikasi perilaku tanah berdasarkan hasil uji sondir (Robertson, 2009)

Robertson (2009) merekomendasikan sistem klasifikasi tanah berdasarkan perilaku tanah (Soil Behavior Type, SBT) yang ditentukan dari nilai tahanan ujung sondir dan rasio gesekan yang dinormalisasi. Gambar 2 memperlihatkan distribusi nilai tahanan ujung yang dinormaliasi $\left(\mathrm{Q}_{\mathrm{tn}}\right)$ dan nilai rasio gesekan yang dinormalisasi $\left(F_{r}\right)$ di lokasi ini. Selain itu, Gambar 2 juga menunjukkan bahwa perilaku tanah di lokasi ini didominasi oleh tanah campuran lanau (zona 4), campuran pasir (zona 5), dan tanah pasir (zona 6).

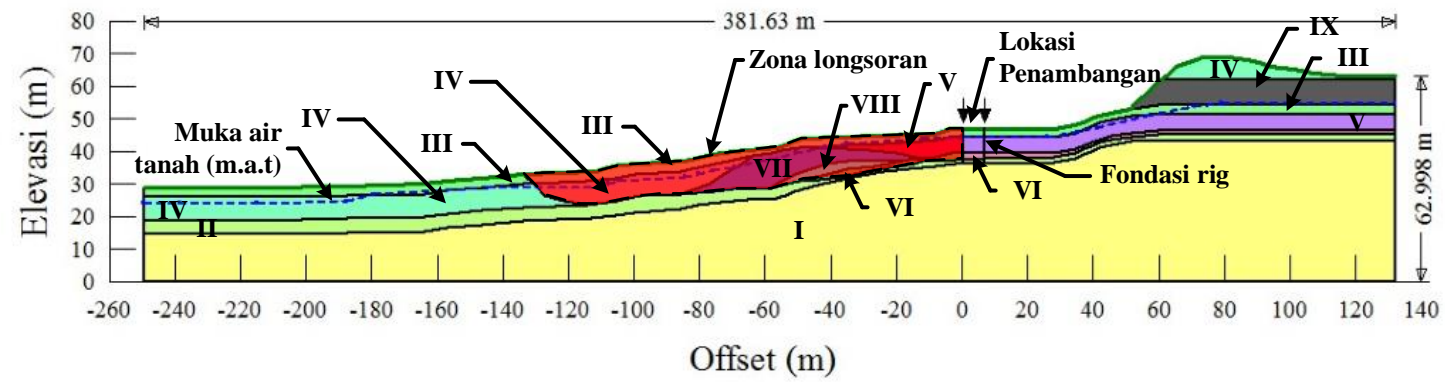

Gambar 3. Estimasi stratifikasi tanah dan pemodelan lereng di SLOPE/W

\section{Penentuan Parameter Tanah dan Analisis Numerik}

\section{Penentuan Parameter Tanah, Stratifikasi Tanah, dan Pemodelan Lereng}

Berdasarkan hasil uji sondir dan klasifikasi perilaku tanah (Gambar 2), tipe perilaku tanah di dalam studi ini kembali dikelompokkan berdasarkan kepadatan atau konsistensi tanahnya menjadi sembilan (9) kelompok. Kelompok tipe perilaku tanah ini kemudian akan digunakan sebagai dasar dalam menentukan stratifikasi tanah dan parameter tanah. Gambar 3 
menggambarkan stratifikasi tanah dan geometri lereng pada kondisi pasca longsoran yang akan digunakan di dalam analisis kestabilan lereng dengan bantuan program SLOPE/W. Zona berwarna merah transparan pada Gambar 3 menggambarkan estimasi zona longsoran berdasarkan pengamatan di lapangan. Lereng dimodelkan dengan panjang total $381,6 \mathrm{~m}$ dan elevasi tertinggi mencapai $69 \mathrm{~m}$. Tabel 1 menunjukkan kelompok tipe perilaku tanah dan rentang serta nilai rata-rata $(\mu)$ berat isi $(\gamma)$, kohesi efektif (c'), sudut geser puncak efektif $\left(\phi_{p}{ }^{\prime}\right)$, dan sudut geser residu efektif $\left(\phi_{\mathrm{r}}{ }^{\prime}\right)$ tanah eksisting. Rentang nilai parameter tanah pada Tabel 1 diestimasikan dengan menggunakan berbagai korelasi empiris berdasarkan nilai $\mathrm{q}_{\mathrm{c}}$ dan $\mathrm{R}_{\mathrm{f}}$ (Jefferies \& Davies, 1983; Bolton, 1986; Wolff, 1989; Budhu, 2010; Robertson \& Cabal, 2010). Sementara itu, nilai rata-rata $(\mu)$ parameter tanah pada Tabel 1 merupakan hasil analisis balik yang dilakukan dengan menggunakan metode kesetimbangan batas dan pendekatan deterministik. Hasil analisis balik menunjukkan bahwa nilai rata-rata sudut geser residu efektif $\left(\mu_{\phi r}\right)$ pada Tabel 1 mendekati nilai sudut geser residu untuk tanah clay shale yang telah terpublikasi (Gartung, 1986; Irsyam et al., 2007). Sebagai catatan, nilai $\phi_{\mathrm{r}}^{\prime}$ pada studi ini hanya diaplikasikan pada lapisan tanah yang berada di dalam zona longsoran (Gambar 3) dan nilai rata-rata kohesi efektif $\left(\mu_{c^{\prime}}\right)$ untuk lapisan tanah di dalam zona longsoran adalah $1,5 \mathrm{kN} / \mathrm{m}^{2}$.

Tabel 1. Estimasi rentang nilai dan rata-rata $(\mu)$ parameter tanah berdasarkan hasil korelasi dan analisis balik

\begin{tabular}{|c|c|c|c|c|c|c|c|}
\hline \multirow{2}{*}{$\begin{array}{l}\text { Tipe perilaku tanah } \\
\text { (kode perlapisan tanah) }\end{array}$} & \multicolumn{2}{|c|}{ Berat isi, $\gamma$} & \multirow{2}{*}{$\begin{array}{l}\text { Kohesi } \\
\text { efektif, } \mu_{\mathrm{c}^{\prime}} \\
\left(\mathbf{k N} / \mathbf{m}^{2}\right)\end{array}$} & \multicolumn{2}{|c|}{$\begin{array}{l}\text { Sudut geser puncak } \\
\text { efektif, } \phi_{p}^{\prime}\end{array}$} & \multicolumn{2}{|c|}{$\begin{array}{c}\text { Sudut geser residu } \\
\text { efektif, } \phi_{r^{\prime}}\end{array}$} \\
\hline & $\begin{array}{c}\text { Rentang } \\
\text { nilai }\end{array}$ & $\begin{array}{c}\boldsymbol{\mu}_{\gamma} \\
\left(\mathbf{k N} / \mathbf{m}^{3}\right)\end{array}$ & & $\begin{array}{c}\text { Rentang } \\
\text { nilai }\end{array}$ & $\begin{array}{c}\mu_{\phi p^{\prime}} \\
\left({ }^{(}\right)\end{array}$ & $\begin{array}{c}\text { Rentang } \\
\text { nilai }\end{array}$ & $\begin{array}{c}\mu_{\phi r^{\prime}} \\
\left({ }^{\circ}\right)\end{array}$ \\
\hline Pasir padat (I) & $18,8-19,5$ & 19,0 & 0,5 & $34,4-38,9$ & 36,9 & - & - \\
\hline Pasir medium (II) & $18,3-19,9$ & 18,6 & 0,5 & $29,8-34,3$ & 31,9 & - & - \\
\hline $\begin{array}{l}\text { Pasir lepas hingga sangat } \\
\text { lepas (III) }\end{array}$ & $16,1-17,3$ & 16,8 & $1,25-1,5$ & $27,4-28,6$ & 28,0 & $9,3-10,1$ & 9,7 \\
\hline $\begin{array}{l}\text { Lempung dan lanau } \\
\text { dengan konsistensi lunak } \\
\text { (IV) }\end{array}$ & $16,7-17,1$ & 16,8 & $1,25-1,5$ & $23,4-32,4$ & 27,8 & $6,6-11,8$ & 9,0 \\
\hline $\begin{array}{l}\text { Lempung atau lanau } \\
\text { dengan konsistensi lunak } \\
\text { hingga sangat lunak (V) }\end{array}$ & $16,2-16,9$ & 16,6 & $1,25-1,5$ & $23,4-30,5$ & 26,6 & $6,6-11,3$ & 8,8 \\
\hline Pasir lepas (VI) & $16,9-18,3$ & 17,5 & $1,25-1,5$ & $25,8-29,9$ & 28,6 & $8,2-11,0$ & 10,1 \\
\hline Pasir lepas (VII) & $16,8-18.7$ & 17,4 & $1,25-1,5$ & - & - & $9,7-12,1$ & 10,3 \\
\hline $\begin{array}{l}\text { Lanau dengan konsistensi } \\
\text { lunak hingga medium } \\
\text { (VIII) }\end{array}$ & $16,7-17,6$ & 17,0 & $1,25-1,5$ & - & - & $7,5-10,4$ & 8,5 \\
\hline Batu bara (IX) & - & 12,0 & $116,7^{\mathrm{a}}$ & $8,0-20,0^{\mathrm{a}}$ & 15,0 & - & - \\
\hline
\end{tabular}

Catatan: a Nilai kohesi dan sudut geser tipikal batu bara menurut Wyllie \& Norrish (1996)

\section{Penentuan Parameter Struktur}

Pada studi ini, terdapat struktur fondasi rig yang digunakan untuk menopang beban dari alat bor dan struktur perkuatan lereng yang digunakan untuk menahan pergerakan lereng. Tiang pancang pipa baja dengan diameter $\left(\mathrm{D}_{\mathrm{f}}\right) 0,46 \mathrm{~m}$, panjang pembenaman tiang $\left(\mathrm{L}_{\mathrm{f}}\right)$ mencapai 10 $\mathrm{m}$, dan spasi antar tiang $\left(\mathrm{S}_{\mathrm{f}}\right) 3 \mathrm{~m}$ digunakan sebagai fondasi rig. Sementara itu, struktur perkuatan lereng yang direkomendasikan untuk lokasi ini adalah dua (2) lapis barisan tiang pancang pipa baja dan cerucuk kayu. Tiang pancang pipa baja untuk struktur perkuatan lereng memiliki diameter tiang $\left(D_{p}\right)$ 0,46 m, panjang tiang $\left(L_{p}\right) 12,5 \mathrm{~m}$, jarak antar tiang $\left(S_{p}\right) 1 \mathrm{~m}$, dan jarak antar barisan tiang $1,5 \mathrm{~m}$. Struktur cerucuk dipasang dengan pola pemasangan segitiga dan jarak antar tiang cerucuk $\left(S_{c}\right)$ 1,5 m. Diameter cerucuk $\left(D_{c}\right)$ yang direkomendasikan adalah $0,1 \mathrm{~m}$, sedangkan panjang tiang minimum $\left(\mathrm{L}_{\mathrm{c}}\right)$ memiliki rentang antara $6 \mathrm{~m}$ hingga $8 \mathrm{~m}$.

Berdasarkan SNI 1729:2015 untuk desain kekuatan izin (DKI) struktur baja, nilai kekuatan geser nominal $\left(\mathrm{V}_{\mathrm{n}}\right)$ tiang pipa baja sebagai parameter input untuk program SLOPE/W diestimasikan sebesar 1.035,6 kN per tiang pancang. Sementara itu, nilai $\mathrm{V}_{\mathrm{n}}$ rata-rata cerucuk kayu sebesar 22,97 kN per tiang cerucuk diestimasikan berdasarkan kapasitas geser rata-rata kayu ulin sebesar $2.925 \mathrm{kN} / \mathrm{m}^{2}$ (Idris dkk., 2019) dikalikan dengan luas penampang cerucuk. Tabel 2 menunjukkan parameter struktur tiang yang digunakan di dalam analisis kestabilan lereng. 
JURNAL REKAYASA KONSTRUKSI MEKANIKA SIPIL (JRKMS)

Tabel 2. Parameter struktur tiang

\begin{tabular}{|c|c|c|c|c|}
\hline $\begin{array}{c}\text { Jenis struktur } \\
\text { perkuatan lereng }\end{array}$ & $\begin{array}{c}\text { Diameter, D } \\
(\mathbf{m})\end{array}$ & $\begin{array}{c}\text { Panjang, } \mathbf{L} \\
(\mathbf{m})\end{array}$ & $\begin{array}{c}\text { Spasi, } \mathbf{S} \\
(\mathbf{m})\end{array}$ & $\begin{array}{c}\text { Kekuatan geser nominal, } \\
\mathbf{V}_{\mathbf{n}}(\mathbf{k N})\end{array}$ \\
\hline Tiang pancang pipa baja & 0,46 & 12,5 & 1,0 & $1.035,60$ \\
\hline Fondasi rig & 0,46 & 10,0 & 3,0 & $1.035,60$ \\
\hline Cerucuk kayu & 0,1 & 6,0 & 1,5 & 22,97 \\
\hline Cerucuk kayu & 0,1 & 8,0 & 1,5 & 22,97 \\
\hline
\end{tabular}

\section{Metode Kesetimbangan Batas dan Analisis Probabilitas Kestabilan Lereng}

Analisis kestabilan lereng dengan metode kesetimbangan batas dilakukan dengan bantuan program SLOPE/W dan dengan mengadopsi prosedur Spencer (1973) untuk menentukan faktor keamanan (FK) lereng. Metode Spencer (1973) merupakan metode paling sederhana di dalam analisis kestabilan lereng berbasis metode kesetimbangan batas yang dapat memenuhi seluruh persyaratan kestimbangan (kesetimbangan momen dan kesetimbangan gaya baik dalam arah vertikal maupun horizontal) (Duncan et al., 2014). Selain itu, metode Spencer (1973) dapat digunakan pada tanah berlapis dan di semua geometri lereng. Kemudian, material model MohrCoulomb digunakan untuk memodelkan kekuatan tanah di dalam studi ini. Jenis analisis yang digunakan adalah analisis tegangan efektif (effective stress analysis) dengan parameter kekuatan efektif (effective strength parameters) yang terdiri dari kohesi efektif ( $\mathrm{c}^{\prime}$ ) dan sudut geser dalam efektif $\left(\phi^{\prime}\right)$. GEO-SLOPE (2015) menyatakan bahwa analisis dengan menggunakan kekuatan tanah efektif dapat memberikan hasil yang paling realistis, khususnya dalam memprediksikan lokasi bidang gelincir kritis. Sebagai catatan, lokasi muka air tanah diperhitungkan di dalam analisis tegangan efektif.

Analisis kestabilan lereng dengan pendekatan probabilistik berbasis simulasi Monte-Carlo juga dilakukan di dalam studi ini dengan menggunakan program SLOPE/W untuk memperoleh nilai probabilitas kegagalan $\left(\mathrm{P}_{\mathrm{f}}\right)$. Simulasi Monte-Carlo memerlukan jumlah simulasi $\left(\mathrm{N}_{\mathrm{mc}}\right)$ yang relatif besar untuk menghasilkan nilai $\mathrm{P}_{\mathrm{f}}$ yang akurat. Semakin besar nilai $\mathrm{N}_{\mathrm{mc}}$, semakin akurat hasil dari simulasi Monte-Carlo (GEO-SLOPE, 2015). Dengan demikian, pada studi ini, nilai $\mathrm{N}_{\mathrm{mc}}$ divariasikan untuk mengetahui jumlah simulasi minimum yang diperlukan untuk mendapatkan nilai $\mathrm{P}_{\mathrm{f}}$ yang relatif akurat atau stabil. Nilai $\mathrm{N}_{\mathrm{mc}}$ yang digunakan adalah 2.000, $5.000,10.000$, dan 20.000 simulasi.

Tabel 3. Nilai standar deviasi ( $\sigma)$ dan koefisien variasi (COV) parameter tanah $\gamma, \phi_{\mathrm{p}}{ }^{\prime}$, dan $\phi_{\mathrm{r}}{ }^{\prime}$

\begin{tabular}{|c|c|c|c|c|c|c|}
\hline \multirow{2}{*}{$\begin{array}{l}\text { Tipe perilaku tanah } \\
\text { (kode perlapisan tanah) }\end{array}$} & \multicolumn{2}{|c|}{ Berat isi, $\gamma$} & \multicolumn{2}{|c|}{$\begin{array}{l}\text { Sudut geser puncak } \\
\text { efektif, } \phi_{\mathrm{p}}^{\prime}\end{array}$} & \multicolumn{2}{|c|}{$\begin{array}{c}\text { Sudut geser residu } \\
\text { efektif, } \phi_{r^{\prime}}\end{array}$} \\
\hline & $\boldsymbol{\sigma}_{\gamma}$ & $\mathrm{COV}_{\gamma}$ & $\boldsymbol{\sigma}_{\phi p^{\prime}}$ & $\mathrm{COV}_{\phi \mathrm{p}^{\prime}}$ & $\sigma_{\phi r^{\prime}}$ & $\mathrm{COV}_{\phi \mathbf{r}^{\prime}}$ \\
\hline Pasir padat $(\mathrm{I})$ & 0,211 & $1,11 \%$ & 1,514 & $4,11 \%$ & - & - \\
\hline Pasir medium (II) & 0,222 & $1,19 \%$ & 1,114 & $3,50 \%$ & - & - \\
\hline Pasir lepas hingga sangat lepas (III) & 0,418 & $2,50 \%$ & 0,350 & $1,25 \%$ & 0,234 & $2,42 \%$ \\
\hline $\begin{array}{l}\text { Lempung dan lanau dengan konsistensi } \\
\text { lunak (IV) }\end{array}$ & 0,098 & $0,58 \%$ & 2,777 & $9,98 \%$ & 1,594 & $17,63 \%$ \\
\hline $\begin{array}{l}\text { Lempung atau lanau dengan konsistensi } \\
\text { lunak hingga sangat lunak }(\mathrm{V})\end{array}$ & 0,245 & $1,48 \%$ & 2,111 & $7,92 \%$ & 1,407 & $16,07 \%$ \\
\hline Pasir lepas (VI) & 0,407 & $2,33 \%$ & 1,435 & $5,02 \%$ & 0,957 & $9,52 \%$ \\
\hline Pasir lepas (VII) & 0,445 & $2,56 \%$ & - & - & 0,426 & $4,15 \%$ \\
\hline $\begin{array}{l}\text { Lanau dengan konsistensi lunak hingga } \\
\text { medium (VIII) }\end{array}$ & 0,241 & $1,41 \%$ & - & - & 0,910 & $10,68 \%$ \\
\hline Batu bara (IX) & 0,600 & $5,00 \%{ }^{\mathrm{a}}$ & 1,125 & $7,50 \%{ }^{\mathrm{a}}$ & - & - \\
\hline
\end{tabular}

Catatan: ${ }^{a}$ Nilai koefisien variasi (coefficient of variance, $\mathrm{COV}$ ) rata-rata berdasarkan data terpublikasi oleh Duncan (2000).

Selain jumlah simulasi, simulasi Monte-Carlo di SLOPE/W memerlukan beberapa parameter input, yaitu jenis fungsi densitas probabilitas (probability density function, PDF), nilai rata-rata $($ mean,$\mu)$, rentang nilai parameter tanah, dan standar deviasi $(\sigma)$ yang ditentukan dari kumpulan data parameter tanah yang tersedia. Pada studi ini, parameter tanah $\gamma, \phi_{\mathrm{p}}{ }^{\prime}, \phi_{\mathrm{r}}{ }^{\prime}$, dan kedalaman muka air tanah dimodelkan secara probabilistik dengan model distribusi normal (GEO-SLOPE, 2015). Nilai $\mu_{\gamma}, \mu_{\phi p^{\prime}}$, dan $\mu_{\phi r^{\prime}}$ ditentukan berdasarkan hasil analisis balik, sedangkan untuk rata- 
rata kedalaman muka air tanah diperoleh berdasarkan hasil observasi sumur pantau (Gambar $3)$. Kemudian, nilai standar deviasi dari parameter berat isi $\left(\sigma_{\gamma}\right)$, sudut geser puncak efektif $\left(\sigma_{\phi p^{\prime}}\right)$, dan sudut geser residu efektif $\left(\sigma_{\phi r^{\prime}}\right)$ diestimasikan berdasarkan statistik parameter $\gamma, \phi_{p}{ }^{\prime}$, dan $\phi_{r}^{\prime}$, sedangkan standar deviasi untuk muka air tanah diasumsikan sebesar 0.5. Tabel 1 menunjukkan rentang nilai parameter tanah dan nilai $\mu$ untuk setiap kelompok tipe perilaku tanah, sedangkan Tabel 3 menunjukkan nilai $\sigma$ dan nilai koefisien variasi (COV) dari masingmasing kelompok tanah. Nilai COV pada studi ini digunakan khususnya untuk menentukan nilai standar deviasi pada lapisan batu bara.

Selanjutnya, analisis sensitivitas dilakukan di dalam studi ini untuk mengetahui pengaruh perubahan kedalaman muka air tanah dan parameter tanah seperti $\gamma, \phi_{\mathrm{p}}{ }^{\prime}$, dan $\phi_{\mathrm{r}}{ }^{\prime}$ terhadap nilai faktor keamanan (FK). Analisis sensitivitas serupa dengan analisis probabilistik, namun parameter tanah dipilih secara berurutan menggunakan fungsi densitas probabilitas seragam (GEO-SLOPE, 2015). Pada studi ini, parameter tanah $\gamma, \phi_{\mathrm{p}}{ }^{\prime}$, dan $\phi_{\mathrm{r}}^{\prime}$ variasikan sesuai dengan rentang nilai yang ditunjukkan pada Tabel 1. Selain itu, kedalaman muka air tanah juga divariasikan dengan asumsi kedalaman muka air tanah dapat bervariasi mulai dari 2,5 $\mathrm{m}$ di atas kedalaman muka air tanah rata-rata hingga 2,5 m di bawah kedalaman muka air tanah rata-rata. Perlu dicatat bahwa seluruh parameter input untuk analisis sensitivitas di SLOPE/W divariasikan secara independen atau hanya satu parameter yang berganti dalam satu kali analisis (GEO-SLOPE, 2015).

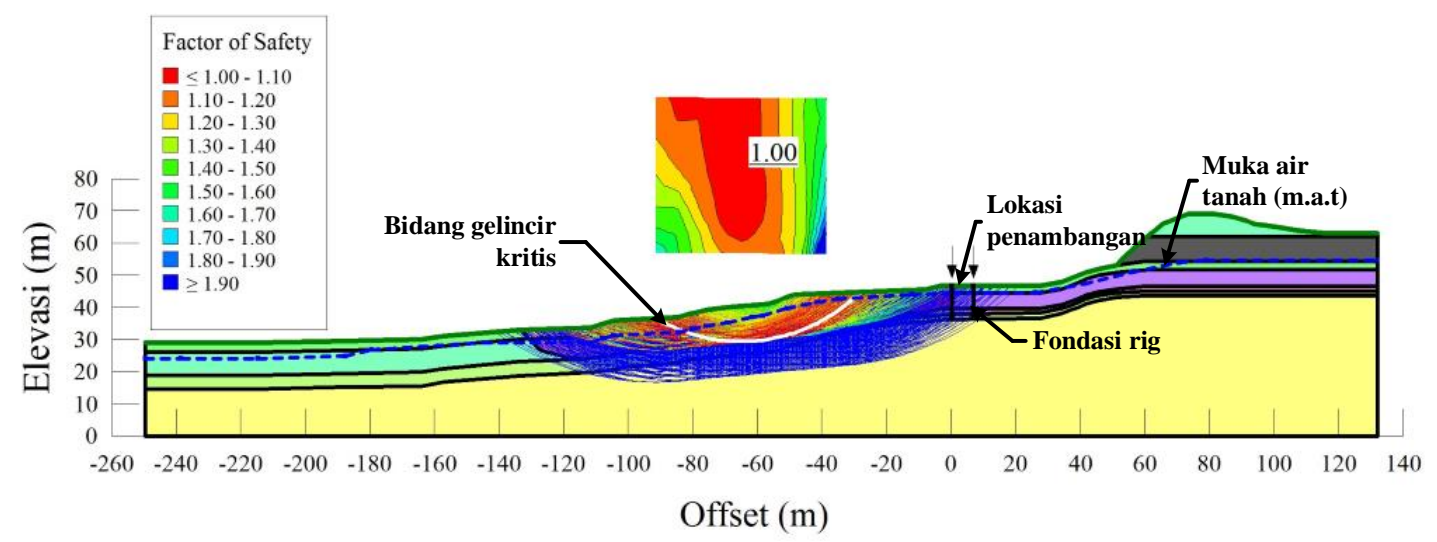

Gambar 4. Estimasi lokasi bidang gelincir kritis berdasarkan hasil analisis balik

\section{Hasil dan Pembahasan}

Gambar 4 menunjukkan hasil analisis balik dengan pendekatan deterministik berupa faktor keamanan (FK) bernilai satu (1) dan lokasi bidang gelincir kritis. Hasil pada Gambar 4 juga mengindikasikan bahwa longsoran translasi dengan ketebalan massa tanah yang berpotensi untuk bergerak mencapai $10 \mathrm{~m}$ terjadi diatas lapisan tanah keras. Pada Gambar 3, lapisan tanah keras disimbolkan dengan kode perlapisan tanah I dan II. Hasil serupa ditunjukkan oleh Pratama \& Arif (2021) yang menggunakan metode elemen hingga, PLAXIS 2D untuk melakukan analisis balik. Berdasarkan nilai FK yang diperoleh pada Gambar 4, upaya perbaikan lereng diperlukan untuk meningkatkan nilai FK.

Peningkatan nilai FK secara umum dapat dilakukan dengan menurunkan tegangan geser yang terjadi pada tanah dengan cara menggali tanah eksisting dan/atau meningkatkan gaya penahan dengan memasang sistem perkuatan lereng. Sehingga, penggalian sedalam $3 \mathrm{~m}$ dari muka tanah eksisting kemudian direkomendasikan untuk mengurangi tegangan geser yang terjadi akibat berat sendiri tanah. Selain itu, perkuatan lereng dengan menggunakan dua (2) lapis barisan tiang pancang dan cerucuk kayu perlu dilakukan untuk meningkatkan kestabilan lereng. Tabel 2 menunjukkan dimensi minimum dan konfigurasi struktur perkuatan lereng. Sebagai tambahan, terdapat timbunan dengan tinggi mencapai $5 \mathrm{~m}$ di kaki lereng yang akan digunakan sebagai lokasi penambangan (Pratama \& Arif, 2021). Pada studi ini, material tanah timbunan diasumsikan memiliki $\mu_{\gamma}=17 \mathrm{kN} / \mathrm{m}^{3}$ dan kuat geser tak terdrainase $\left(\mathrm{s}_{\mathrm{u}}\right)=50 \mathrm{kN} / \mathrm{m}^{2}$. Beban 
alat bor diasumsikan sebesar $25 \mathrm{kN} / \mathrm{m}^{2}$ dan beban pelat lantai kerja sebesar $6,1 \mathrm{kN} / \mathrm{m}^{2}$. Pelat lantai kerja hanya digunakan di lokasi penambangan yang berada di atas lereng karena kondisi tanah yang relatif lunak. Gambar 5 menunjukkan nilai FK hasil analisis kestabilan lereng dengan pendekatan deterministik setelah barisan tiang pancang dan cerucuk kayu diaplikasikan, yaitu 1,25 . Nilai FK $=1,25$ telah memenuhi kriteria FK minimum untuk lereng tanah yang disyaratkan oleh SNI 8460:2017, yaitu 1,25.

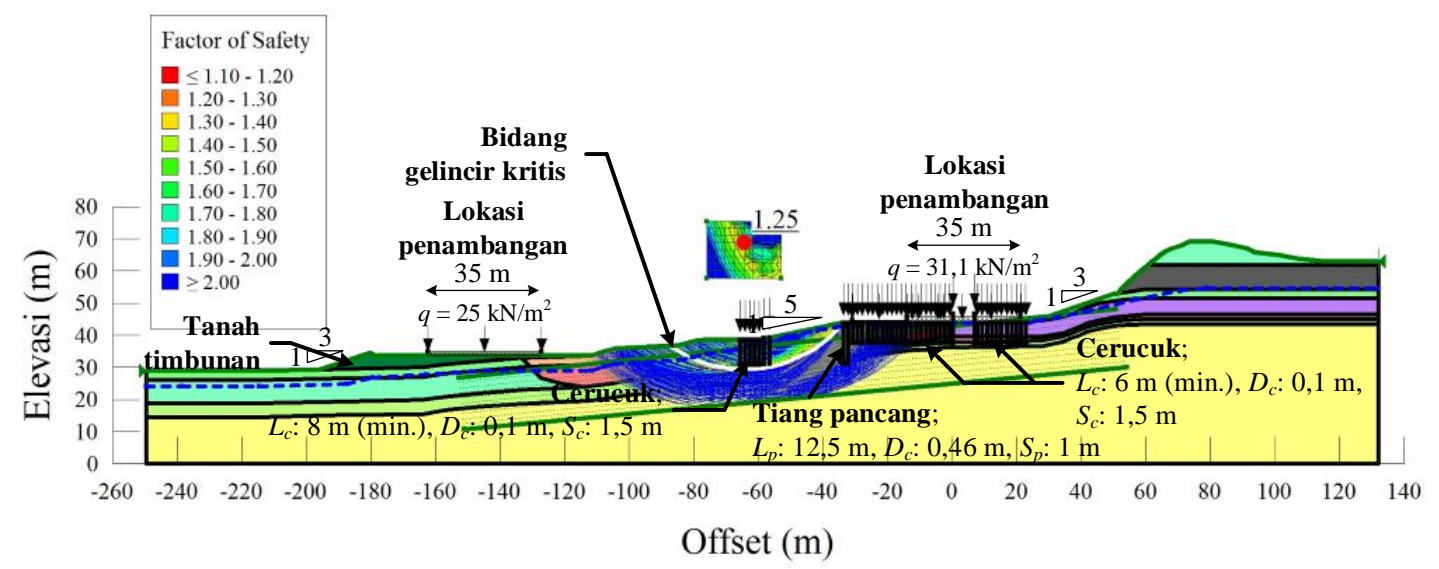

Gambar 5. Faktor keamanan lereng dengan perkuatan tiang pancang dan cerucuk

Tabel 4. Nilai faktor keamanan (FK) dan probabilitas kegagalan $\left(\mathrm{P}_{\mathrm{f}}\right)$ sebelum dan setelah menggunakan

\begin{tabular}{|c|c|c|c|c|c|c|c|c|}
\hline \multirow{2}{*}{ Kondisi analisis } & \multicolumn{2}{|c|}{$\mathbf{N}_{\mathrm{mc}}=\mathbf{2 . 0 0 0}$} & \multicolumn{2}{|c|}{$\mathbf{N}_{\mathrm{mc}}=\mathbf{5 . 0 0 0}$} & \multicolumn{2}{|c|}{$\mathbf{N}_{\mathrm{mc}}=\mathbf{1 0 . 0 0 0}$} & \multicolumn{2}{c|}{$\mathbf{N}_{\mathrm{mc}}=\mathbf{2 0 . 0 0 0}$} \\
\cline { 2 - 9 } & $\mathbf{F K}$ & $\mathbf{P}_{\mathbf{f}}(\boldsymbol{\%})$ & $\mathbf{F K}$ & $\mathbf{P}_{\mathbf{f}} \mathbf{( \% )}$ & $\mathbf{F K}$ & $\mathbf{P}_{\mathbf{f}}(\mathbf{\%})$ & $\mathbf{F K}$ & $\mathbf{P}_{\mathbf{f}}(\boldsymbol{\%})$ \\
\hline $\begin{array}{c}\text { Lereng eksisting (tanpa } \\
\text { perkuatan) }\end{array}$ & 1,014 & 39,2 & 1,013 & 40,9 & 1,013 & 40,5 & 1,015 & 39,8 \\
\hline $\begin{array}{c}\text { Lereng dengan struktur } \\
\text { perkuatan }\end{array}$ & 1,264 & 0,05 & 1,262 & 0,28 & 1,263 & 0,15 & 1,265 & 0,15 \\
\hline
\end{tabular}

Hasil analisis probabilistik kestabilan lereng berbasis simulasi Monte-Carlo pada Tabel 4 menunjukkan bahwa pada studi kasus ini, jumlah simulasi $\left(\mathrm{N}_{\mathrm{mc}}\right)$ tidak memberikan dampak signifikan terhadap perubahan nilai FK, walaupun terjadi sedikit peningkatan nilai FK apabila dibandingkan dengan nilai FK hasil dari analisis kestabilan lereng dengan pendekatan deterministik. Namun, perubahan nilai $\mathrm{N}_{\mathrm{mc}}$ dapat mempengaruhi nilai $\mathrm{P}_{\mathrm{f}}$. Semakin besar nilai $\mathrm{N}_{\mathrm{mc}}$, maka nilai $\mathrm{P}_{\mathrm{f}}$ akan semakin relatif stabil. Untuk $\mathrm{N}_{\mathrm{mc}}=2.000,5.000,10.000$, dan 20.000 simulasi, nilai $\mathrm{P}_{\mathrm{f}}$ pada kondisi lereng eksisting secara berturut-turut adalah 39,2\%, 40,9\%, $40,5 \%$, dan $39,8 \%$. Sementara itu, nilai $\mathrm{P}_{\mathrm{f}}$ pada kondisi lereng dengan struktur perkuatan adalah $0,05 \%, 0,28 \%, 0,15 \%$, dan $0,15 \%$ untuk nilai $\mathrm{N}_{\mathrm{mc}}=2.000,5.000,10.000$, dan 20.000 simulasi secara berturut-turut. Hasil ini mengindikasikan bahwa penambahan nilai $\mathrm{N}_{\mathrm{mc}}$ hingga lebih dari 10.000 simulasi akan menghasilkan nilai $\mathrm{P}_{\mathrm{f}}$ yang relatif stabil. Namun, studi lebih lanjut dengan menggunakan studi kasus lain dan dengan nilai $\mathrm{N}_{\mathrm{mc}}$ yang lebih besar direkomendasikan untuk memverifikasi hasil studi ini karena nilai $\mathrm{N}_{\mathrm{mc}}$ yang dibutuhkan dapat berubah tergantung pada jumlah variabel yang diperhitungkan dan tingkat kepercayaan (level of confidence) terhadap hasil perhitungan (GEO-SLOPE, 2015). Sebagai contoh, untuk tingkat kepercayaan 80\% dengan 2 variabel yang diperhitungkan, nilai $\mathrm{N}_{\mathrm{mc}}$ yang diperlukan adalah 100 simulasi, sedangkan untuk tingkat kepercayaan 90\% dengan 2 variabel yang diperhitungkan, nilai $\mathrm{N}_{\mathrm{mc}}$ yang diperlukan adalah 4.489 (GEO-SLOPE, 2015). Hal ini mengindikasikan semakin banyak jumlah simulasi, maka hasil yang diperoleh akan semakin akurat, namun waktu yang dibutuhkan untuk melakukan analisis akan semakin panjang.

Tabel 4 juga menunjukkan bahwa penggunaan struktur perkuatan pada lereng dapat menurunkan nilai $P_{f}$. Nilai $P_{f}$ pada saat kondisi lereng eksisting adalah $40,5 \%$ untuk nilai $\mathrm{N}_{\mathrm{mc}}$ $=10.000$ simulasi, sedangkan $P_{f}$ pada saat kondisi lereng dengan struktur perkuatan adalah $0,15 \%$. Namun, nilai $P_{f}=0,15 \%$ belum dapat memenuhi kriteria target probabilitas kegagalan 
$\left(\mathrm{P}_{\mathrm{f}}^{*}\right)$ yang direkomendasikan oleh USACE (1997) dan beberapa investigator (Wu et al., 2014; Goh et al., 2008), yaitu 0,1\%. Sehingga, salah satu upaya untuk menurunkan nilai $\mathrm{P}_{\mathrm{f}}$ adalah dengan melakukan penyelidikan tanah tambahan untuk menurunkan tingkat ketidakpastian parameter tanah.

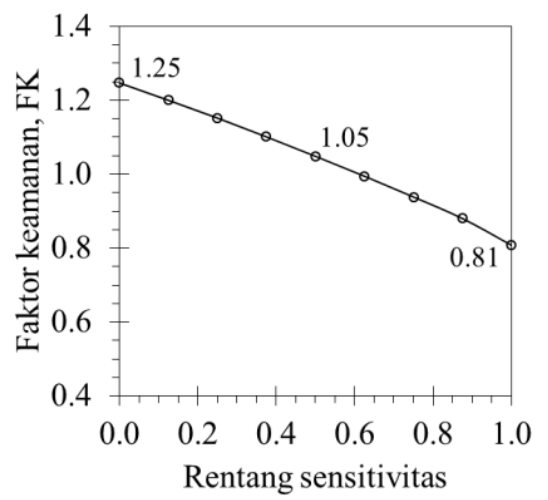

(a)

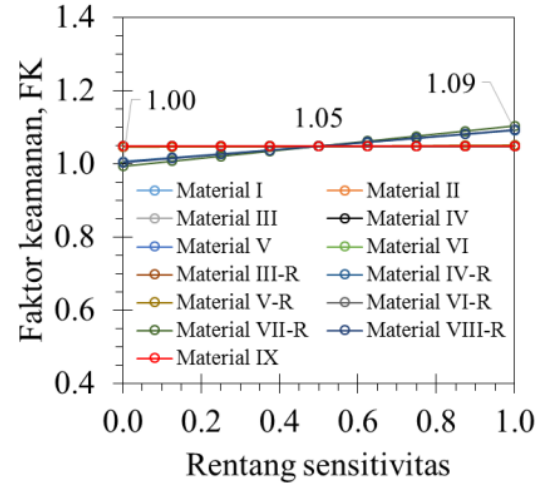

(b)

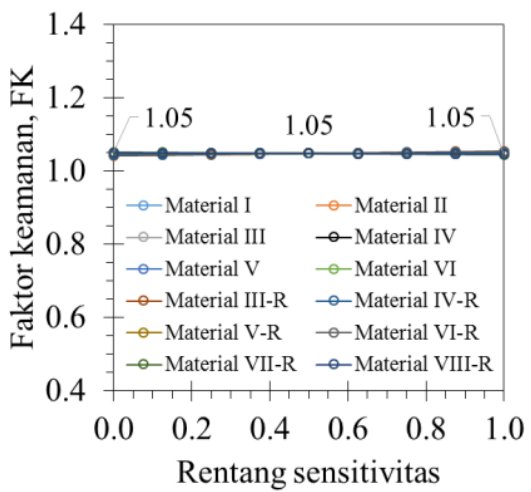

(c)

Gambar 6. Kurva faktor keamanan (FK) terhadap rentang sensitivitas parameter (a) kedalaman muka air tanah, (b) sudut geser puncak efektif $\left(\phi_{\mathrm{p}}{ }^{\prime}\right)$ dan sudut geser residu $\left(\phi_{\mathrm{r}}{ }^{\prime}\right)$, dan $(\mathrm{c})$ berat isi tanah $(\gamma)$ untuk kondisi lereng eksisting

Gambar 6 dan Gambar 7 menggambarkan kurva FK terhadap sensitivitas parameter berat isi $(\gamma)$, sudut geser puncak efektif $\left(\phi_{\mathrm{p}}{ }^{\prime}\right)$ dan sudut geser residu $\left(\phi_{\mathrm{r}}{ }^{\prime}\right)$, dan kedalaman muka air pada kondisi lereng eksisting dan lereng dengan struktur perkuatan secara berturut-turut. Pada Gambar 6 dan Gambar 7, rentang sensitivitas menyatakan nilai parameter tanah yang dinormalisasi menjadi nilai yang memiliki rentang antara 0 hingga 1 . Nilai nol (0) mengindikasikan nilai terendah dalam suatu rentang parameter, sedangkan nilai satu (1) menggambarkan nilai tertinggi. Sebagai contoh, rentang nilai $\gamma$ untuk lapisan tanah pasir padat (I) adalah $18,8 \mathrm{kN} / \mathrm{m}^{3}$ hingga $19,5 \mathrm{kN} / \mathrm{m}^{3}$ (Tabel 1), maka nilai nol (0) merepresentasikan $\gamma=$ $18,8 \mathrm{kN} / \mathrm{m}^{3}$ dan nilai satu (1) merepresentasikan $\gamma=19,5 \mathrm{kN} / \mathrm{m}^{3}$. Sebagai tambahan, simbol “R" pada Gambar 6 dan Gambar 7 mengartikan bahwa nilai $\phi_{\mathrm{r}}$ digunakan pada jenis material terkait di dalam analisis sensitivitas.

Hasil analisis sensitivitas menunjukkan bahwa kedalaman muka air tanah merupakan variabel paling sensitif di dalam analisis kestabilan lereng clay shale (Gambar 6a dan Gambar 7a). Hal ini diindikasikan oleh kemiringan kurva pada Gambar 6a dan Gambar 7a yang relatif curam dibandingkan dengan kurva sensitivitas lainnya. Gambar 6a dan Gambar 7a juga menggambarkan bahwa nilai FK menurun seiring dengan peningkatan muka air tanah dan tekanan air pori. Akibat peningkatan tekanan air pori pada tanah, kekuatan geser tanah sebagai salah satu komponen gaya penahan pergerakan lereng akan menurun, sehingga nilai FK juga akan menurun. Hasil serupa ditemukan oleh Alonso (1976) yang melakukan studinya pada tanah lempung sensitif di Kanada. 


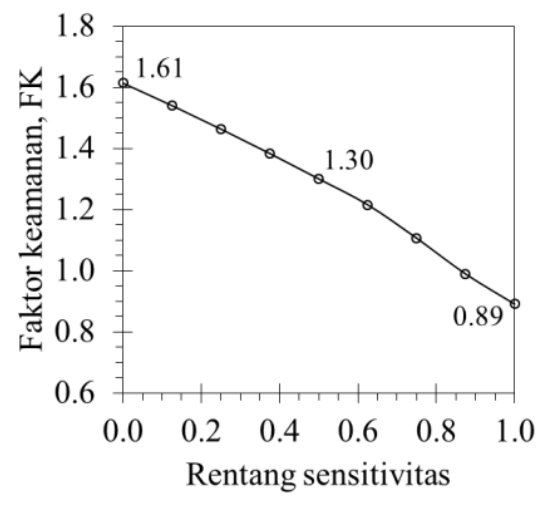

(a)

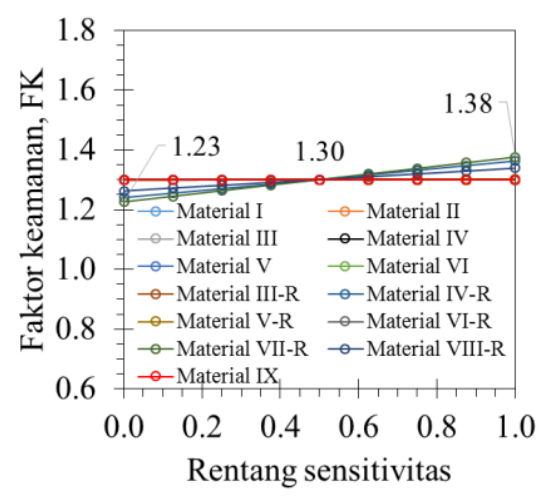

(b)

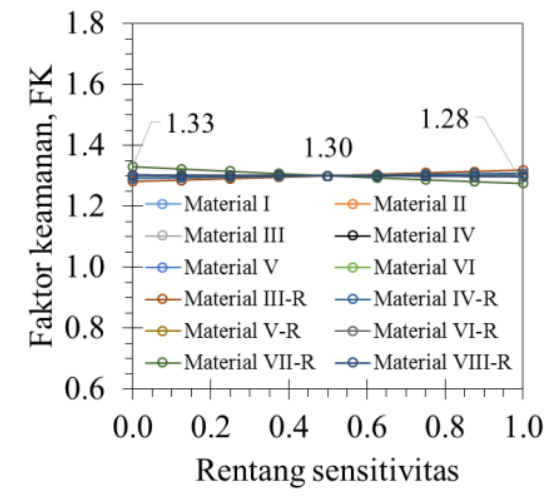

(c)

Gambar 7. Kurva faktor keamanan (FK) terhadap rentang sensitivitas parameter (a) kedalaman muka air tanah, (b) sudut geser puncak efektif $\left(\phi_{\mathrm{p}}^{\prime}\right)$ dan sudut geser residu $\left(\phi_{\mathrm{r}}^{\prime}\right)$, dan (c) berat isi tanah $(\gamma)$ untuk kondisi lereng dengan struktur perkuatan

Selain kedalaman muka air yang memiliki pengaruh terhadap nilai FK lereng clay shale di dalam studi ini, nilai $\phi_{r}^{\prime}$ material IV, VII, dan VIII juga mempengaruhi nilai FK (Gambar 6b dan Gambar 7b). Semakin besar nilai $\phi_{\mathrm{r}}^{\prime}$ material IV, VII, dan VIII, maka semakin besar nilai FK dan berlaku sebaliknya. Namun, perubahan nilai $\phi_{\mathrm{p}}{ }^{\prime}$ dan $\phi_{\mathrm{r}}{ }^{\prime}$ pada lapisan tanah lain tidak mengakibatkan perubahan signifikan terhadap nilai FK. Hal ini disebabkan oleh lokasi material IV, VII, dan VIII yang berada di dalam zona longsoran dan memotong bidang longsor kritis (Gambar 4 dan Gambar 5), sehingga nilai $\phi_{\mathrm{r}}^{\prime}$ material IV, VII, dan VIII berdampak langsung terhadap perhitungan nilai FK. Kemudian, pada studi ini, parameter $\gamma$ memiliki pengaruh paling kecil terhadap nilai FK (Gambar 6c dan Gambar 7c). Hal ini dapat disebabkan oleh rentang nilai $\gamma$ yang relatif kecil sehingga perubahan nilai $\gamma$ tidak memberikan pengaruh signifikan terhadap perhitungan nilai FK. Hasil serupa juga diindikasikan oleh Agam et al. (2016).

\section{Kesimpulan}

Pada studi ini dilakukan analisis deterministik dan probabilistik kestabilan lereng clay shale di Kalimantan. Analisis kestabilan lereng dilakukan dengan menggunakan metode Spencer pada program kesetimbangan batas, SLOPE/W untuk mengestimasikan nilai faktor keamanan. Sementara itu, analisis probabilistik berbasis simulasi Monte-Carlo dilakukan untuk memperoleh nilai probabilitas kegagalan lereng. Analisis balik pertama-tama dilakukan untuk memperoleh parameter tanah yang mendekati kondisi di lapangan. Hasil analisis balik menunjukkan bahwa nilai sudut geser residu efektif di lokasi studi ini memiliki rentang antara $8,5^{\circ}$ hingga $10,3^{\circ}$, sedangkan untuk nilai kohesi efektif tanah clay shale bernilai $1,5 \mathrm{kN} / \mathrm{m}^{2}$. Selain itu, hasil analisis balik juga mengindikasikan bahwa longsoran translasi terjadi di atas lapisan tanah keras. Pemasangan struktur perkuatan berupa barisan tiang pipa baja dan cerucuk kayu dan penggalian tanah eksisting sedalam 3 dapat meningkatkan faktor keamanan lereng pada kasus ini menjadi 1,25. 
Berdasarkan hasil analisis probabilistik, jumlah simulasi pada simulasi Monte-Carlo di dalam studi ini tidak memiliki pengaruh signifikan terhadap nilai faktor keamanan, namun berpengaruh terhadap nilai probabilitas kegagalan lereng, khususnya pada kondisi lereng dengan perkuatan. Hasil analisis probabilistik mengindikasikan bahwa jumlah simulasi MonteCarlo sebesar 10.000 simulasi dianggap sudah dapat menghasilkan nilai faktor keamanan dan probabilitas yang relatif konsisten. Namun, hal ini memerlukan verifikasi lebih lanjut dengan melakukan simulasi Monte-Carlo dengan jumlah simulasi yang lebih besar. Selain itu, analisis probabilistik kestabilan lereng dengan menggunakan studi kasus lain untuk memvalidasi kesimpulan pada studi ini juga direkomendasikan. Lebih lanjut, hasil analisis probabilitas juga mengindikasikan bahwa penggunaan struktur perkuatan lereng dapat menurunkan probabilitas kegagalan lereng. Namun, nilai probabilitas kegagalan yang diperoleh masih melebihi nilai target probabilitas kegagalan yang direkomendasikan oleh beberapa investigator, yaitu $0,1 \%$. Sehingga, penyelidikan tanah tambahan diperlukan untuk mengurangi tingkat ketidakpastian parameter tanah dan probabilitas kegagalan lereng.

Hasil analisis sensitivitas pada studi ini menunjukkan bahwa kedalaman muka air tanah berperan penting dalam perhitungan nilai faktor keamanan lereng clay shale, sedangkan parameter berat isi tanah memiliki pengaruh paling kecil terhadap perhitungan nilai faktor keamanan. Sehingga, di dalam desain kestabilan lereng clay shale, kontrol muka air tanah berperan penting dalam menjaga kestabilan lereng.

\section{Ucapan Terima Kasih}

Penulis mengucapkan terima kasih kepada Center for Geohazards (C4GH), Universitas Katolik Parahyangan (Unpar) karena telah memberikan kesempatan untuk berpartisipasi di dalam proses desain perbaikan dan perkuatan lereng, serta izin untuk menggunakan data sebagai bahan studi ini. Selain itu, penulis juga mengucapkan terima kasih kepada Bapak Budijanto Widjaja, Ph.D., Bapak Dr. Cindarto Lie, M.Sc., dan Bapak Aswin Lim, Ph.D. atas saran dan bimbingan selama proses desain perkuatan lereng di lokasi ini.

\section{Referensi}

Agam, M. W., Hashim, M. H. M., Murad, M. I., \& Zabidi, H. (2016). Slope sensitivity analysis using Spencer's Method in comparison with general limit Equilibrium method. Procedia Chemistry, 19, 651-658. https://doi.org/10.1016/j.proche.2016.03.066

Alonso, E. E. (1976). Risk analysis of slopes and its application to slopes in Canadian sensitive clays. Géotechnique, 26(3), 453-472. https://doi.org/10.1680/geot.1976.26.3.453

Bolton, M. D. (1987). Discussion: The strength and dilatancy of sands. Géotechnique, 37(4), 517. https://doi.org/10.1680/geot.1987.37.4.517

Budhu, M. (2010). Soil Mechanics and Foundations (3rd ed.). Wiley.

Duncan, J. M. (2000). Factors of safety and reliability in geotechnical engineering. Journal of Geotechnical and Geoenvironmental Engineering, 126(4), 307-316. https://doi.org/10.1061/(asce)1090-0241(2000)126:4(307)

Duncan, M. J., Wright, S. G., \& Brandon, T. L. (2014). Soil strength and slope stability (2nd ed.). Wiley.

El-Ramly, H., Morgenstern, N. R., \& Cruden, D. M. (2003). Probabilistic stability analysis of a tailings dyke on presheared clay-shale. Canadian Geotechnical Journal, 40(1), 192-208. https://doi.org/10.1139/t02-095

Gartung, E. (1986). Excavation in hard clays of the Keuper Formation. Symposium on Geotechnical Aspects of Stiff and Hard Clays (pp. 69-83).

GEO-SLOPE International Ltd. (2015). Stability modeling with SLOPE/W. GEO-SLOPE International Ltd.

Goh, A. T. C., Kulhawy, F. H., \& Wong, K. S. (2008). Reliability assessment of basal-heave stability for braced excavations in clay. Journal of Geotechnical and Geoenvironmental Engineering, 134(2), 145-153. https://doi.org/10.1061/(asce)1090-0241(2008)134:2(145)

Gouw, T. L., \& Gunawan, A. (2019). Slope stabilization by use of geosynthetics in clay shale formation. International Conference on Landslide and Slope Stability (pp. D1-1-D1-13).

Idris, M., Kamaldi, A., \& Novan, A. (2019). Kekuatan tekan sejajar dan geser kayu ulin (Eusideroxylon Zwageri) di Kota Pekanbaru berdasarkan SNI 7973:2013. Jurnal Teknik, 13(1), 85-93. https://doi.org/10.31849/teknik.v13i1.2971

Irsyam, M., Susila, E., \& Himawan, A. (2007). Slope failure of an embankment on clay shale at KM 
$97+500$ of the Cipularang Toll Road and the selected solution. International Symposium on Geotechnical Engineering, Ground Improvement, and Geosynthetics for Human Security and Environmental Preservation (pp. 531-540).

Jefferies, M.G., \& Davies, M.P. (1993). Use of CPTu to estimate equivalent SPT N60. Geotechnical Testing Journal, 16(4), 458. https://doi.org/10.1520/gtj10286j

Jitno, H., Lailatin, Pratiwi, F., \& Satwikawati, N. L. (2019). Soil reinforcement of highway embankment on clay shale foundation. International Conference on Landslide and Slope Stability (pp. D7-1D7-9).

Hsein Juang, C., Zhang, J., \& Gong, W. (2015). Reliability-based assessment of stability of slopes. IOP Conference Series: Earth and Environmental Science, 26(1). https://doi.org/10.1088/1755$1315 / 26 / 1 / 012006$

Lacasse, S., \& Nadim, F. (1998). Risk and reliability in geotechnical engineering. Fourth International Conference on Case Histories in Geotechnical Engineering (pp. 1172-1192).

Badan Standardisasi Nasional Indonesia. Spesifikasi untuk Bangunan Gedung Baja Struktural (SNI 1729:2015).

Badan Standardisasi Nasional Indonesia. Persyaratan Perancangan Geoteknik (SNI 8460:2017).

Pratama, I. T., \& Arif, A. Y. (2021). Analisis numerik perkuatan lereng dengan menggunakan barisan tiang pancang dan cerucuk pada tanah clay shale di Kalimantan. Simposium Nasional Teknologi Infrastruktur Abad ke-21 (pp. 629-635).

Robertson, P. K. (2009). Interpretation of cone penetration tests - A unified approach. Canadian Geotechnical Journal, 46(11), 1337-1355. https://doi.org/10.1139/t09-065

Robertson, P. K., \& Cabal, K. L. (2010). Estimating soil unit weight from CPT. $2^{\text {nd }}$ International Symposium on Cone Penetration Testing.

Spencer, E. (1973). Thrust line criterion in embankment stability analysis. Géotechnique, 23(1), 85-100. https://doi.org/10.1680/geot.1973.23.1.85

Tobutt, D. (1982). Monte Carlo Simulation methods for slope stability. Computers and Geosciences, 8(2), 199-208. https://doi.org/10.1016/0098-3004(82)90021-8

USACE. (1997). Engineering and design: Risk-based analysis in geotechnical engineering for support of planning studies. Engineer Technical Letter 1110-2-556. U.S. Army Corps of Engineers (USACE).

Wang, Y., Cao, Z., \& Au, S. K. (2010). Efficient Monte Carlo Simulation of parameter sensitivity in probabilistic slope stability analysis. Computers and Geotechnics, 37(7-8), 1015-1022. https://doi.org/10.1016/j.compgeo.2010.08.010

Wolff, T. F. (1989). Pile capacity prediction using parameter functions. Predicted and Observed Axial Behavior of Piles: Results of a Pile Prediction Symposium (pp. 96-106).

Wu, S. H., Ou, C. Y., \& Ching, J. (2014). Calibration of model uncertainties in base heave stability for wide excavations in clay. Soils and Foundations, 54(6), 1159-1174. https://doi.org/10.1016/j.sandf.2014.11.010

Wyllie, D. C., \& Norrish, N. I. (1996). Rock Strength Properties and Their Measurement. Dalam Schuster, R.L., \& Turner, A.K., Landslide: Investigation and Mitigation (hlm. 372-390). National Academy Press.

Zhou, X., Huang, W., Li, J., \& Chen, D. (2020). Robust geotechnical design for soil slopes considering uncertain parameters. Mathematical Problems in Engineering, 2020, 1-11. https://doi.org/10.1155/2020/5190580 


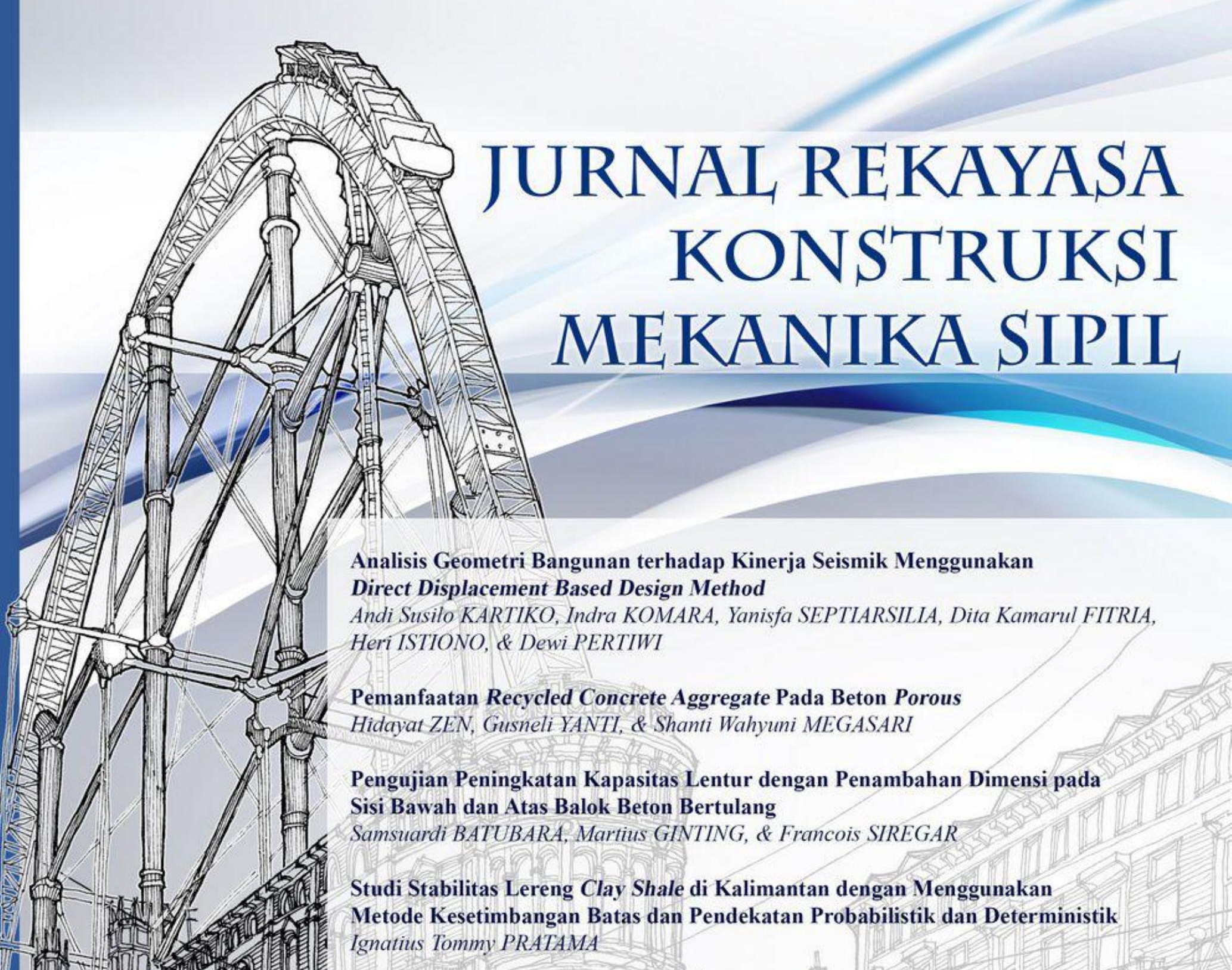

Pengaruh Tata Guna Lahan terhadap Kinerja Jalan dan Biaya Tundaan Lalu Lintas Koridor Jalan GOR Mustika Kabupaten Blora

Hartono Guntur RISTIYANTO \& Salma MFIRDAUS

Kinerja Moda Bus Trans Mebidang Trayek Lubuk Pakam-Pusat Pasar Medan di Masa Pandemi Covid-19

Oloan SITOHANG, Reynaldo SIAHAAN, \& Arnoldus Yansen Berkat LAIA

Perbandingan Produktivitas Tenaga Kerja Pembesian dan Bekisting Saat Jam Kerja Normal dan Lembur Menggunakan Metode Productivity Rating Caroline Maretha SUJANA \& Raka Aditya HAKIM

Analisis Faktor-Faktor yang Mempengaruhi Produktivitas Tenaga Kerja pada Proyek Pembangunan Jalan Tol Ruas Binjai-Langsa Seksi Binjai-Pangkalan Brandan Yolanda Ayu DAMAYANTI \& Mizanuddin SITOMPUL

Fakultas Teknik 


\section{Jurnal Rekayasa Konstruksi Mekanika Sipil (JRKMS)}

Jurnal Rekayasa Konstruksi Mekanika Sipil (JRKMS) Fakultas Teknik Universitas Katolik Santo Thomas berisi artikel-artikel ilmiah yang meliputi kajian di bidang teknik khususnya Teknik Sipil, seperti matematika teknik, mekanika teknik, analisis struktur, konstruksi baja, konstruksi beton, konstruksi kayu, konstruksi gelas, mekanika tanah, teknik pondasi, hidrologi, hidrolika, bangunan air, manajemen konstruksi, dinamika struktur, earthquake engineering, sistem dan rekayasa transportasi, ilmu ukur tanah, struktur bangunan sipil, rekayasa jalan raya, serta penelitian-penelitian lain yang terkait dengan bidang-bidang tersebut.

Terbit dalam 2 (dua) kali setahun yaitu pada bulan April dan September

\section{Penasihat :}

Prof. Dr. Drs. Sihol Situngkir, MBA. (Rektor Universitas Katolik Santo Thomas)

Ketua Penyunting (Editor in Chief) :

Ir. Oloan Sitohang, M.T. (Universitas Katolik Santo Thomas)

Manajer Penyunting (Managing Editor):

Reynaldo, S.T., M.Eng. (Universitas Katolik Santo Thomas)

\section{Anggota Penyunting (Editorial Board):}

Dr.-Ing. Sofyan S.T, M.T. (Universitas Malikussaleh)

Ir. Martius Ginting, M.T. (Universitas Katolik Santo Thomas)

Samsuardi Batubara, S.T., M.T. (Universitas Katolik Santo Thomas)

Dr. Janner Simarmata (Universitas Negri Medan)

\section{Mitra Bestari (Peer Reviewer):}

Dr.Eng. Ir. Aleksander Purba, S.T., M.T., IPM, ASEAN Eng. (Universitas Lampung, Indonesia)

Ir. Binsar Silitonga, M.T. (Universitas Katolik Santo Thomas, Indonesia)

Budi Hasiholan, S.T., M.T., Ph.D (Institut Teknologi Bandung, Indonesia)

Ir. Charles Sitindaon, M.T. (Universitas Katolik Santo Thomas, Indonesia)

Dr. Erica Elice Uy (De La Salle University, Philippines)

Dr. Ernesto Silitonga, S.T, D.E.A. (Universitas Negeri Medan, Indonesia)

Prof. Dr-Ing. Johannes Tarigan (Universitas Sumatera Utara, Indonesia)

Linda Prasetyorini (Universitas Brawijaya, Malang, Indonesia)

Dr.Eng. Mia Wimala (Universitas Katolik Parahyangan, Indonesia)

Dr.Eng. Minson Simatupang (Universitas Halu Oleo, Indonesia)

Dr. Mochamad Raditya Pradana (Keppel Marine and Deepwater Technology, Singapura)

Dr. Ir. Shirly Susanne Lumeno, S.T., M.T. (Universitas Negeri Manado, Indonesia)

Dr. Senot Sangadji (Universitas Sebelas Maret, Indonesia)

Ir. Simon Dertha, M.T. (Universitas Katolik Santo Thomas, Indonesia)

Dr. Thi Nguyên Cao (Tien Giang University, Viet Nam)

Budijanto Widjaja, S.T., M.T., Ph.D, (Guest Vol.4.No.2) (Universitas Katolik Parahyangan, Indonesia)

\section{Ilustrator Sampul:}

Yulianto, ST., M.Eng

\section{Penerbit \& Alamat Redaksi:}

Fakultas Teknik Universitas Katolik Santo Thomas

Jl. Setiabudi No. 479-F Tanjung Sari, Medan 20132

Telp. (061) 8210161 Fax : (061) 8213269

email : unika.sipil@yahoo.com 


\title{
Konten
}

\author{
REKAYASA STRUKTUR \\ Analisis Geometri Bangunan terhadap Kinerja Seismik Menggunakan \\ Direct Displacement Based Design Method \\ Andi Susilo KARTIKO, Indra KOMARA, Yanisfa SEPTIARSILIA, Dita Kamarul \\ FITRIA, Heri ISTIONO, \& Dewi PERTIWI
}

hal.

$73-84$

Pemanfaatan Recycled Concrete Aggregate Pada Beton Porous

Hidayat ZEN, Gusneli YANTI, \& Shanti Wahyuni MEGASARI

Pengujian Peningkatan Kapasitas Lentur dengan Penambahan Dimensi

pada Sisi Bawah dan Atas Balok Beton Bertulang

Samsuardi BATUBARA, Martius GINTING, \& Francois SIREGAR

\section{REKAYASA GEOTEKNIK}

Studi Stabilitas Lereng Clay Shale di Kalimantan dengan Menggunakan

Metode Kesetimbangan Batas dan Pendekatan Probabilistik dan

Deterministik

Ignatius Tommy PRATAMA

\section{REKAYASA TRANSPORTASI}

Pengaruh Tata Guna Lahan terhadap Kinerja Jalan dan Biaya Tundaan

Lalu Lintas Koridor Jalan GOR Mustika Kabupaten Blora

Hartono Guntur RISTIYANTO \& Salma M FIRDAUS

Kinerja Moda Bus Trans Mebidang Trayek Lubuk Pakam-Pusat Pasar

Medan di Masa Pandemi Covid-19

Oloan SITOHANG, Reynaldo SIAHAAN, \& Arnoldus Yansen Berkat LAIA

\section{MANAJEMEN KONSTRUKSI}

Perbandingan Produktivitas Tenaga Kerja Pembesian dan Bekisting Saat Jam Kerja Normal dan Lembur Menggunakan Metode Productivity Rating Caroline Maretha SUJANA \& Raka Aditya HAKIM

Analisis Faktor-Faktor yang Mempengaruhi Produktivitas Tenaga Kerja pada Proyek Pembangunan Jalan Tol Ruas Binjai-Langsa Seksi BinjaiPangkalan Brandan

Yolanda Ayu DAMAYANTI \& Mizanuddin SITOMPUL 


\section{Pengantar Redaksi}

Puji dan syukur kami sampaikan kepada Tuhan Yang Maha Esa karena atas kasih karuniaNYA kami dapat menyelesaikan penerbitan Jurnal Rekayasa Konstruksi Mekanika Sipil (JRKMS) Volume 4 Nomor 2, di bulan September tahun 2021 ini. Jurnal ini fokus pada beragam subbidang dalam Teknik Sipil antara lain Rekayasa Struktur, Rekayasa Geoteknik, Rekayasa Transportasi, Teknik Sumber Daya Air, dan Manajemen Konstruksi. Namun, tidak menutup kesempatan bagi subbidang lainnya yang berkaitan dengan keilmuan Teknik Sipil.

Satu hal yang patut disyukuri pula adalah semakin terkendalinya kondisi pandemi COVID-19 di Indonesia. Hal ini turut menjadi angin segar pendorong bagi kita untuk meningkatkan semangat meneliti dan berkontribusi pada bidang keilmuan kita. Pada edisi ini, kami menerima banyak artikel dengan topik yang menarik. Ada 8 peer-reviewed artikel yang terbit di Volume 4 Nomor 2 ini, yang mana terdiri atas 3 (tiga) artikel dalam topik Rekayasa Struktur, 1 (satu) artikel dalam topik Rekayasa Geoteknik, 2 (dua) artikel dalam topik Rekayasa Transportasi, 2 (dua) artikel dalam topik Manajemen Konstruksi.

Seiring dengan semakin tingginya tuntutan kualitas publikasi ilmiah oleh pemerintah, pada edisi ini tim editorial berusaha meningkatkan kualitas review dan penyuntingan dengan harapan semakin baik pula kapasitas kita bersama, dan kualitas artikel ilmiah yang kita terbitkan. Dewan redaksi menyampaikan apresiasi tinggi kepada para penulis yang tulisannya diterbitkan pada volume ini, atas kerja samanya merespon komentar dan rekomendasi dari tim editorial dan mitra bestari. Kami menyadari bahwa butuh dedikasi dan investasi waktu untuk menghasilkan karya tulis yang baik dan bermanfaat. Terkhusus, kami bersyukur atas para mitra bestari yang tidak pernah lelah dalam menyambut permintaan kami dengan penuh dedikasi.

Sebagai penutup, harapan kami adalah semoga jurnal ini dapat menjadi media ilmiah yang bermanfaat dan informatif bagi rekan-rekan dan praktisi bidang ketekniksipilan di Indonesia. Salam hangat dan Salam sehat.

Medan, September 2021

Tim Editorial 
